\title{
Primary hypothyroidism with pituitary hyperplasia characterized by hypogonadotropic hypogonadism: a case report and review of the literature
}

\author{
Wenshu $\mathrm{Yu}^{1}, \mathrm{Na} \mathrm{Wu}^{1,2}$ \\ ${ }^{1}$ Department of Endocrinology, Shengjing Hospital of China Medical University, Shenyang, China; ${ }^{2}$ Clinical Skill Practice Teaching Center, \\ Shengjing Hospital of China Medical University, Shenyang, China \\ Correspondence to: Na Wu. Department of Endocrinology, Shengjing Hospital of China Medical University, 36 Sanhao Road, Heping District, \\ Shenyang, China. Email: 3441535223@qq.com.
}

\begin{abstract}
Primary hypothyroidism with pituitary hyperplasia is a rare entity. It is characterized by hypogonadotropic hypogonadism and growth hormone $(\mathrm{GH})$ deficiency. Despite advances in imaging, it is still not possible to clearly distinguish pituitary hyperplasia from pituitary tumors. We describe a case of primary hypothyroidism associated with pituitary hyperplasia. We reviewed 18 case reports of children or adolescents with short stature or hypogonadotropic hypogonadism from 2001 to 2019. In the present report, we studied a 15 -year-old adolescent male whose first diagnosis was low gonadotropin development and growth retardation. Imaging examination revealed nodular signals in the saddle area of the pituitary gland, and endocrine function tests showed primary hypothyroidism. Levothyroxine tablets were taken as replacement therapy. A literature search found that 17 studies reported delayed bone age and growth retardation, but only 6 studies measured GH; 5 studies showed a decrease in GH. To distinguish primary hypothyroidism with subsequent pituitary hyperplasia from pituitary tumors, the definitive diagnosis should be based on clinical symptoms, endocrine examination, and prognosis following medication. For patients with hypothyroidism, thyroid hormone replacement therapy can result in a satisfactory prognosis, as well as improvements in clinical symptoms and serologic values. The pituitary function of those with pituitary hyperplasia can be slowly restored after negative feedback inhibition is rebalanced. However, patients with pituitary tumors should undergo surgery.
\end{abstract}

Keywords: Primary hypothyroidism; hypogonadotropic hypogonadism; pituitary hyperplasia; pituitary tumors

Submitted Aug 11, 2020. Accepted for publication Nov 03, 2020.

doi: 10.21037/apm-20-1828

View this article at: http://dx.doi.org/10.21037/apm-20-1828

\section{Introduction}

Hypothyroidism is a systemic low-metabolic syndrome caused by decreased synthesis and secretion of thyroid hormone or insufficient tissue utilization (1). Pituitary hyperplasia accounts for $25-81 \%$ of hypothyroidism cases (2). In 1851, Niépce et al. first reported cases of hypothyroidism characterized by pituitary hyperplasia; since then, there have been many related reports (3). A continuous lack of negative thyroid hormone feedback has been found to cause excessive thyrotropin-releasing hormone (TRH) secretion. This leads to compensatory pituitary gland enlargement, and a subsequent increase in the production of thyroid-stimulating hormone (TSH) (4). A continuous lack of negative thyroid hormone feedback also stimulates thyroid gland development and enlargement. It is rare for pituitary enlargement from primary hyperthyroidism to cause other pituitary hormone deficiencies [gonadotrophin and growth hormone (GH) deficiency] (2). In central hypothyroidism caused by pituitary tumor, free T4 level is low, TSH may be decreased or slightly increased (5). Because of the different treatment methods, the pituitary hyperplasia caused by primary hypothyroidism is treated with left thyroid 
replacement therapy, while pituitary adenoma is usually treated by surgery. Therefore, it is very important to make a definite diagnosis and identify it by laboratory examination, clinical manifestations and imaging examination. Despite advances in imaging technology in recent years, magnetic resonance imaging (MRI) is still unable to accurately identify pituitary hyperplasia or pituitary tumors (6). In many cases, levothyroxine replacement therapy can identify pituitary hyperplasia and prevent the misdiagnosis of pituitary tumors, to reduce the irreversible damage resulting from unnecessary surgery $(7,8)$.

Primary hypothyroidism with pituitary hyperplasia may lead to hyperprolactinemia and high-gonadotropin hypogonadism. Cases of hypothyroidism with decreased gonadotropin, GH, and pituitary enlargement are relatively rare (2). In the present study, we report on an adolescent male with symptoms of hypogonadotropic hypogonadism, reduced follicle-stimulating hormone (FSH), luteinizing hormone (LH), and GH deficiency. An MRI indicated that the lesion was a pituitary tumor. We reviewed 18 related cases and summarized their clinical manifestations, laboratory and imaging examinations, and treatment outcomes. We present the following article in accordance with the CARE reporting checklist (available at http:// dx.doi.org/10.21037/apm-20-1828).

\section{Materials and methods}

\section{Case presentation}

All procedures performed in studies involving human participants were in accordance with the ethical standards of the institutional and/or national research committee(s) and with the Helsinki Declaration (as revised in 2013). Written informed consent was obtained from the patient.

A 15-year-old male was referred to Shengjing Hospital of China Medical University due to "growth retardation for 5 years, penis not growing for 2 years". In the past 5 years, his height increased by $2 \mathrm{~cm}$. In the past 2 years, his penis did not grow and his appetite was poor, but his body weight gradually increased. The patient gradually became lethargic, less verbal, and less interested in activities. His academic performance was still good, but his memory was poor. No obvious abnormality was found in the other hospital (thyroid function was not tested and other specific tests are not detailed). Finally, the patient visited our hospital for further diagnosis and treatment. On July 19, 2018, the patient was admitted to the Endocrinology Department of our hospital.
During his hospitalization, his appetite was suppressed and he was unable to sleep; however, there were no changes in his body weight.

Physical examination showed that his body temperature was $36^{\circ} \mathrm{C}$, pulse was 70 beats $/ \mathrm{min}$, blood pressure was $100 / 62 \mathrm{mmHg}$, respiratory rate was 18 breaths/min, height was $148 \mathrm{~cm}(<3 \mathrm{rd})$, and body weight was $62.5 \mathrm{~kg}$. The patient had abdominal obesity; no rough skin, laryngeal prominence, facial hair, or pubertal gynecomastia was noted. The external genitalia had no pubic hair (Tanner grade 1). The length of the stretched penis was $2.5 \mathrm{~cm}$. The testes were measured by a Prader orchidometer and 3-dimensional ultrasound. The left testicular volume was $10 \mathrm{~mL}$, and the right testicular volume was $9 \mathrm{~mL}$. The patient's verbal and non-verbal expressions were normal, and the result of the neurological examination was also normal.

The laboratory examination results are shown in Table 1. There were no significant abnormalities in the glycated albumin, glycosylated hemoglobin, blood gas analysis, routine urine, liver and kidney function, blood lipids, serum ion, parathyroid hormone values, or the rheumatoid arthritis blood test. Laboratory analyses found that the free thyroxine (FT4) level was low $(7.45 \mathrm{pmol} / \mathrm{L}$, normal range: 9.01-19.05 pmol/L), human GH (hGH) level was comparatively low $(0.068 \mathrm{ng} / \mathrm{mL}$, standard: 0.004 $1.406 \mathrm{ng} / \mathrm{mL})$, and TSH level was high $(40.7562 \mathrm{uIU} / \mathrm{mL}$, normal range: $0.30-4.80 \mathrm{uIU} / \mathrm{mL}$ ). The patient's bone age was 12 years, which was 3 years younger than his actual age. Color Doppler ultrasound showed diffuse thyroid lesions, uneven distribution of internal echo, and strong echo of coarse grid sample. The results of the sex hormone test indicated that the testosterone level was low $(<0.1 \mathrm{ng} / \mathrm{mL}$, normal range: $1.75-7.81 \mathrm{ng} / \mathrm{mL}$ ). Gonadotropin was detected by electrochemiluminescence immunoassay using the Beckman Coulter kit; the results showed that FSH and $\mathrm{LH}$ levels were low (FSH: $4.97 \mathrm{mIU} / \mathrm{mL}$, normal range: $1.27-19.26 \mathrm{mIU} / \mathrm{mL}$; LH: $0.37 \mathrm{mIU} / \mathrm{mL}$, normal range: $1.24-8.62 \mathrm{mIU} / \mathrm{mL})$. The gonadotropin-releasing hormone $(\mathrm{GnRH})$ stimulation test (intravenous injection of $0.1 \mathrm{mg}$ $\mathrm{GnRH}+10 \mathrm{~mL}$ normal saline) showed that the LH peak was low (time 0(test start time): FSH: $6.33 \mathrm{mIU} / \mathrm{mL}$, normal range: $1.27-19.26 \mathrm{mIU} / \mathrm{mL}$; $\mathrm{LH}: 0.85 \mathrm{mIU} / \mathrm{mL}$, normal range: $1.24-8.62 \mathrm{mIU} / \mathrm{mL}$. Time 30 : FSH: $7.46 \mathrm{mIU} / \mathrm{mL}$; LH: $4.11 \mathrm{mIU} / \mathrm{mL}$. Time 60: FSH: $6.63 \mathrm{mIU} / \mathrm{mL}$; LH: $4.14 \mathrm{mIU} / \mathrm{mL}$. Time 90: $\mathrm{FSH}$ $6.88 \mathrm{mIU} / \mathrm{mL}$; LH: $4.23 \mathrm{mIU} / \mathrm{mL}$. Time 120: FSH: $6.88 \mathrm{mIU} / \mathrm{mL}$; LH: $3.79 \mathrm{mIU} / \mathrm{mL}$ ), indicating that the patient had hypogonadotropic hypogonadism (Table 2). 
Table 1 Results of hormonal tests in a 15-year-old adolescent male with hypothyroidism

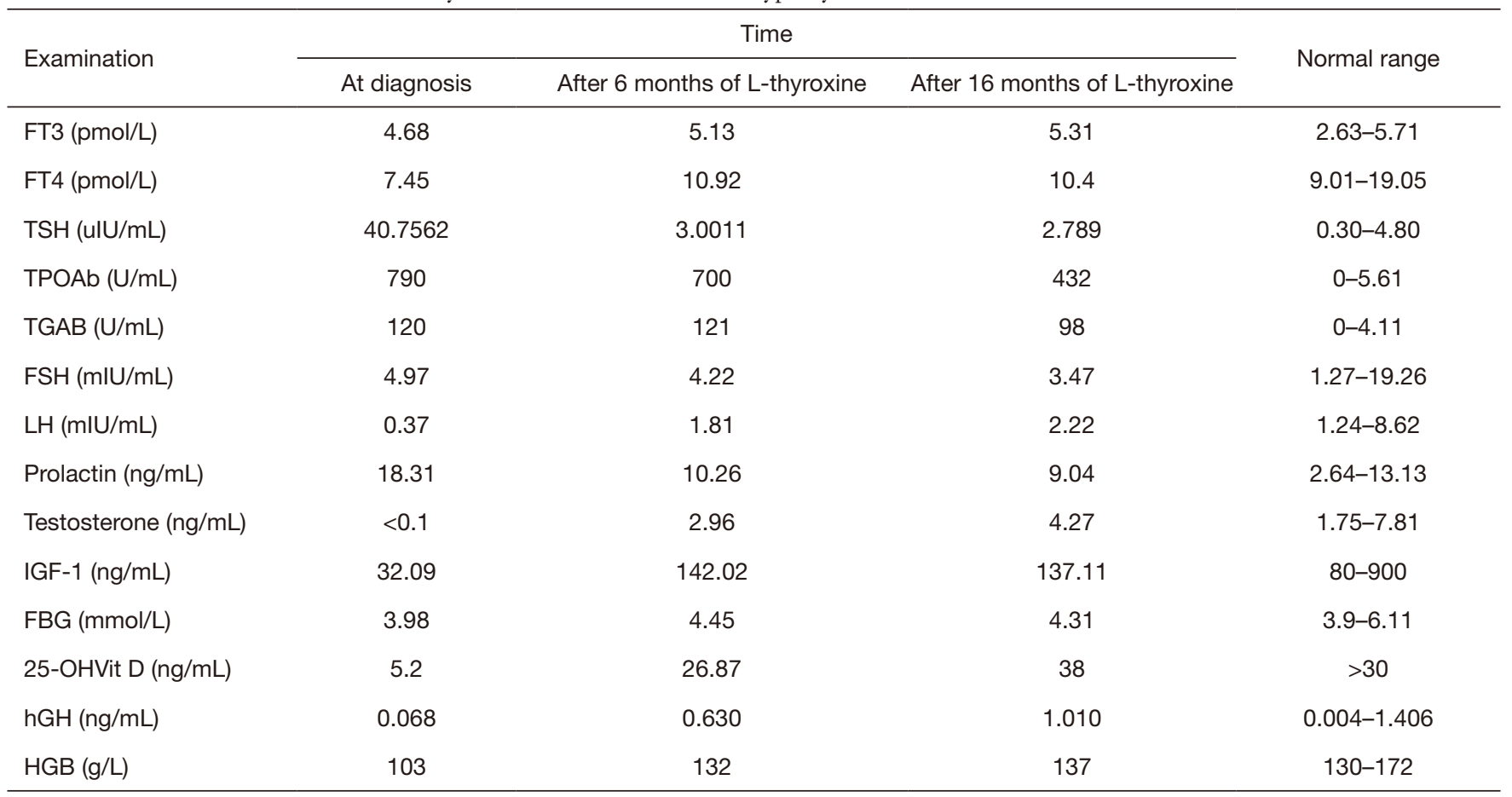

FBG, fasting blood glucose; FSH, follicle-stimulating hormone; FT3, free triiodothyronine; FT4, free thyroxine; hGH, human growth hormone; IGF, insulin-like growth factor; LH, luteinizing hormone; TPOAb, thyroid peroxidase antibodies; TRAB, thyrotropin receptor antibodies; TSH, thyroid-stimulating hormone; 25-OHVit D, 25-OH vitamin D.

Table 2 Result of GnRH stimulation test in a 15-year-old adolescent male with hypothyroidism

\begin{tabular}{|c|c|c|c|c|c|c|}
\hline \multirow{2}{*}{ Time (min) } & \multicolumn{3}{|c|}{ GnRH stimulation test } & \multicolumn{3}{|c|}{ GnRH extension test } \\
\hline & $\mathrm{FSH}(\mathrm{mlU} / \mathrm{mL})^{\dagger}$ & $\mathrm{LH}(\mathrm{mlU} / \mathrm{mL})^{\ddagger}$ & Testosterone $(\mathrm{ng} / \mathrm{mL})^{\S}$ & $\mathrm{FSH}(\mathrm{mlU} / \mathrm{mL})^{\dagger}$ & $\mathrm{LH}(\mathrm{mlU} / \mathrm{mL})^{\ddagger}$ & Testosterone $(\mathrm{ng} / \mathrm{mL})^{\S}$ \\
\hline 0 & 6.33 & 0.85 & $<0.1$ & 1.64 & 0.26 & 0.22 \\
\hline 30 & 7.46 & 4.11 & - & 6.16 & 3.26 & - \\
\hline 60 & 6.63 & 4.14 & - & 6.31 & 4.21 & - \\
\hline 120 & 6.88 & 3.79 & $<0.1$ & 5.31 & 1.57 & 0.22 \\
\hline
\end{tabular}

${ }^{\dagger}$, normal range: $1.27-19.26 \mathrm{mIU} / \mathrm{mL} ;{ }^{\ddagger}$, normal range: $1.24-8.62 \mathrm{mlU} / \mathrm{mL} ;{ }^{\S}$, normal range: $1.75-7.81 \mathrm{ng} / \mathrm{mL}$. GnRH, gonadotropinreleasing hormone; $\mathrm{FSH}$, follicle-stimulating hormone; $\mathrm{LH}$, luteinizing hormone.

The patient underwent GnRH extension tests (intravenous injection of $0.1 \mathrm{mg} \mathrm{GnRH}+10 \mathrm{~mL}$ water for 4 days, and then intravenous injection of $0.1 \mathrm{mg} \mathrm{GnRH}+10 \mathrm{~mL}$ normal saline on day 5), which indicated that the FSH peak was relatively low (time 0(test start time): FSH: $1.64 \mathrm{mIU} / \mathrm{mL}$; LH: $0.26 \mathrm{mIU} / \mathrm{mL}$. Time 30: FSH: $6.16 \mathrm{mIU} / \mathrm{mL}$; LH: $3.26 \mathrm{mIU} / \mathrm{mL}$. Time 60: FSH: $6.31 \mathrm{mIU} / \mathrm{mL}$; LH: $4.21 \mathrm{mIU} / \mathrm{mL}$. Time 90: FSH:
$6.24 \mathrm{mIU} / \mathrm{mL}$; LH: $4.01 \mathrm{mIU} / \mathrm{mL}$. Time 120: FSH: $5.31 \mathrm{mIU} / \mathrm{mL}$; LH: $1.57 \mathrm{mIU} / \mathrm{mL}$ ), further confirming that the patient had hypogonadotropic hypogonadism (Table 2). Hypoglycemic stimulation and the arginine GH test indicated a lack of GH (arginine stimulation test: time 0: GH: $0.055 \mathrm{ng} / \mathrm{mL}$; time 30: $\mathrm{GH}: 1.398 \mathrm{ng} / \mathrm{mL}$; time 60: $\mathrm{GH}: 0.943 \mathrm{ng} / \mathrm{mL}$; time 90: $\mathrm{GH}: 0.355 \mathrm{ng} / \mathrm{mL}$; time 120: $\mathrm{GH}: 0.116 \mathrm{ng} / \mathrm{mL}$. Insulin tolerance test: time 0: 
Table 3 Result of growth hormone stimulation test in a 15-year-old adolescent male with hypothyroidism

\begin{tabular}{lccc}
\hline \multirow{2}{*}{ Time $(\mathrm{min})$} & \multicolumn{2}{c}{ Arginine stimulation test } & \multicolumn{2}{c}{ Insulin tolerance test } \\
\cline { 2 - 3 } 0 & Growth hormone $(\mathrm{ng} / \mathrm{mL})^{\dagger}$ & Growth hormone $(\mathrm{ng} / \mathrm{mL})^{\dagger}$ & Glucose $(\mathrm{mmol} / \mathrm{L})$ \\
30 & 0.055 & 0.033 & 3.88 \\
60 & 1.398 & 0.03 & 1.72 \\
90 & 0.943 & 0.085 & 1.56 \\
120 & 0.355 & 0.131 & 1.41 \\
\hline
\end{tabular}

${ }^{\dagger}$, normal level in growth hormone stimulation tests is $>10 \mathrm{ng} / \mathrm{mL}$.
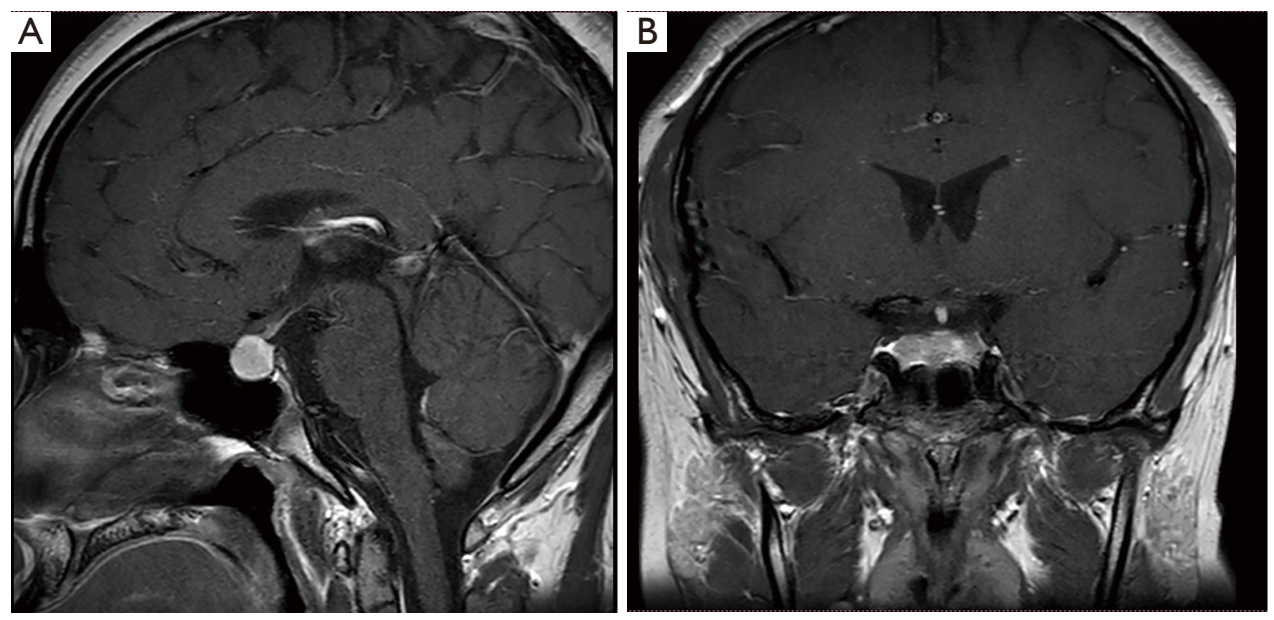

Figure 1 Intracranial magnetic resonance imaging before treatment. (A) Sagittal T1-weighted images; (B) coronal T1-weighted images.

GH: $0.033 \mathrm{ng} / \mathrm{mL}$; time 30: $\mathrm{GH}: 0.030 \mathrm{ng} / \mathrm{mL}$; time 60: GH: $0.085 \mathrm{ng} / \mathrm{mL}$; time $90: \mathrm{GH}: 0.131 \mathrm{ng} / \mathrm{mL}$; time 120 : GH $0.121 \mathrm{ng} / \mathrm{mL}$; a score of $>10 \mathrm{ng} / \mathrm{mL}$ indicates normal GH in stimulation tests) (Table 3). To rule out organic lesions, we performed a brain MRI. The result showed that the pituitary fossa was enlarged, the saddle area had an iso-long T1 and slightly longer T2 nodular signals, the tuberculum sellae was slightly depressed, the pituitary stalk was unclear, and the optic chiasm moved upward. The lesion was enhanced slightly and unevenly. The report suggested a pituitary macroadenoma (Figure 1). Because MRI cannot clearly distinguish pituitary hyperplasia from a pituitary adenoma, we were unable to determine the correct surgical procedure; therefore, the patient was started on levothyroxine replacement therapy.

\section{Literature review}

We performed an extensive review of the literature from
2001 until April 20, 2020 using the CNKI, Elsevier, VIP, NSTL, DOAJ, J-STAGE, Wanfang Medical Network, Springer, PubMed, Research Gate, and Protocols databases. Specific keywords in Chinese and English were used for the literature search. These were as follows: primary hypothyroidism, hypogonadotropic hypogonadism, pituitary hyperplasia, children, and GH. The search strategy was limited to Chinese and English.

\section{Results}

\section{Case presentation}

Six months after thyroxine replacement therapy, endocrine examination showed that thyroid function (free triiodothyronine: $5.13 \mathrm{pmol} / \mathrm{L}$, normal range: 2.63-5.71 pmol/L; FT4: $10.92 \mathrm{pmol} / \mathrm{L}$, normal range: 9.01-19.05 pmol/L; TSH: $3.0011 \mathrm{uIU} / \mathrm{mL}$, normal range: $0.30-4.80 \mathrm{uIU} / \mathrm{mL})$, testosterone $(2.96 \mathrm{ng} / \mathrm{mL}$, normal 

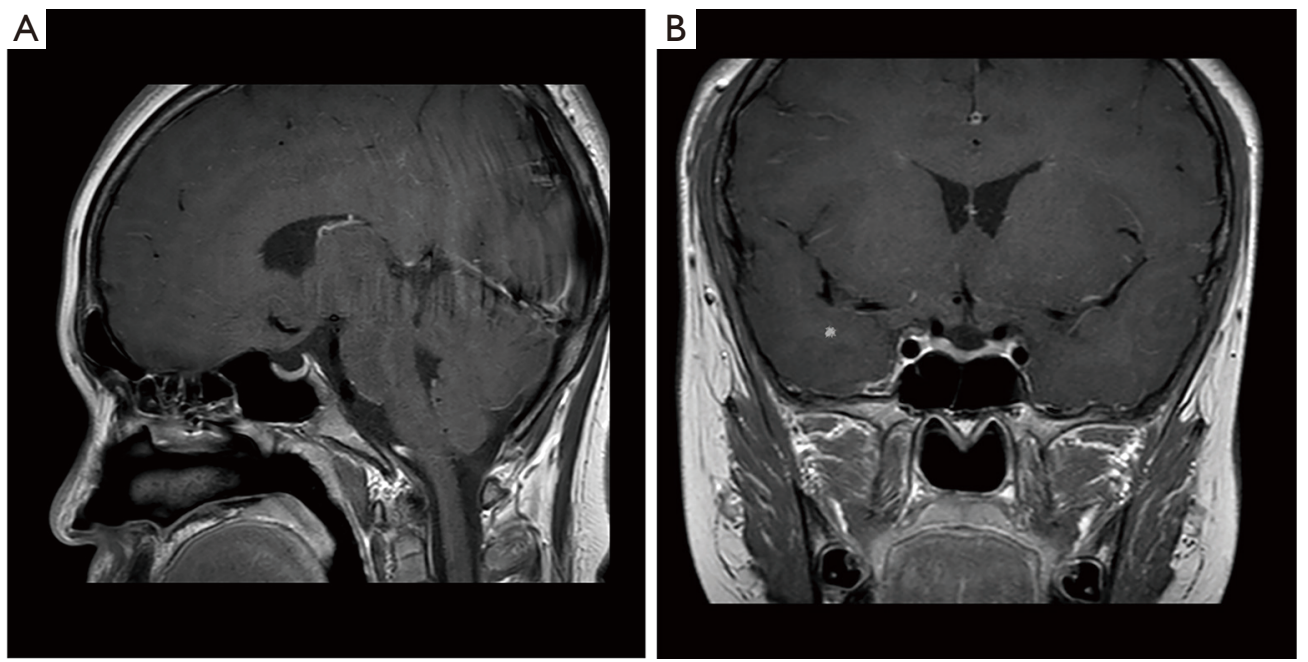

Figure 2 Intracranial magnetic resonance imaging after treatment. (A) Sagittal T1-weighted images; (B) coronal T1-weighted images.

range: $1.75-7.81 \mathrm{ng} / \mathrm{mL}$ ), and $\mathrm{FSH}$ and $\mathrm{LH}$ improved to within normal limits (FSH: $4.22 \mathrm{mIU} / \mathrm{mL}$, normal range: 1.27-19.26 mIU/mL; LH: $1.81 \mathrm{mIU} / \mathrm{mL}$, normal range: 1.24-8.62 mIU/mL) (Table 1). A second MRI examination was performed 6 months after levothyroxine replacement therapy, and showed that the pituitary gland had shrunk; gonadal hormone and $\mathrm{GH}$ had improved to normal levels (testosterone: $4.27 \mathrm{ng} / \mathrm{mL}$, normal range: $1.75-7.81 \mathrm{ng} / \mathrm{mL}$; hGH: $0.630 \mathrm{ng} / \mathrm{mL}$, normal range: $0.004-1.406 \mathrm{ng} / \mathrm{mL}$ ). After 16 months of levothyroxine treatment, the patient's height increased to $161 \mathrm{~cm}$ (> the third percentile, < the 10th percentile). Facial hair began appearing, particularly above the upper lip; his voice began to deepen; armpit hair began to grow; and he had seminal discharge. Pubic hair began to grow on the outer genitalia (Tanner grade 4), and the extended penis was $7 \mathrm{~cm}$ long. Prader orchidometer and 3 -dimensional ultrasound were used for measurements. The volume of the testicles on both sides was $15 \mathrm{~mL}$. Endocrine examination showed that the insulin-like growth factor-1 (IGF-1) level became normal $(137.11 \mathrm{ng} / \mathrm{mL}$, normal range: $80-900 \mathrm{ng} / \mathrm{mL}$ ) (Table 1). Therefore, we diagnosed the patient with primary hypothyroidism with hyperplasia, producing hypogonadotropic hypogonadism and GH deficiency. After levothyroxine replacement therapy, pituitary hyperplasia was reduced and gonadal hormone and GH returned to normal levels (Figure 2).

\section{Literature review}

A total of 880 articles (51 from Chinese databases and 829 from English databases) were collected following a keyword search. After reading the titles and abstracts and omitting duplicates, 85 articles were selected and downloaded. The full text was read, and 18 studies that met the inclusion criteria were selected for the final literature review. We reviewed 18 case reports of children or adolescents with short stature or hypogonadotropic hypogonadism from 2001 to 2019 (Table 4) (7,9-25). Of these, 17 studies reported delayed bone age and growth retardation $(7,9-23,25)$, but only 6 studies measured GH, with 5 studies reporting a decrease in $\mathrm{GH}(10,12,18,19,25)$.

\section{Discussion}

Congenital hypothyroidism and acquired hypothyroidism are common causes of primary thyroid dysfunction. Congenital hypothyroidism is mainly caused by endemic iodine deficiency, thyroid hypoplasia, and ectopic thyroid gland-induced low thyroxine biosynthesis. In contrast, the most common cause of acquired hypothyroidism is autoimmune thyroiditis. Primary hypothyroidism is often diagnosed in late prepubertal years due to Hashimoto's thyroiditis, and can cause increased testicular volume (10). A combination of positive thyroid autoantibodies and color Doppler ultrasound can lead to the diagnosis of Hashimoto's thyroiditis with hypothyroidism. Thyroid hormone level as a negative feedback regulatory signal affects the production of pituitary hormones. The negative feedback decreased the sensitivity of TSH cells to TRH and inhibited the secretion of TSH. Conversely, the lack of negative feedback 


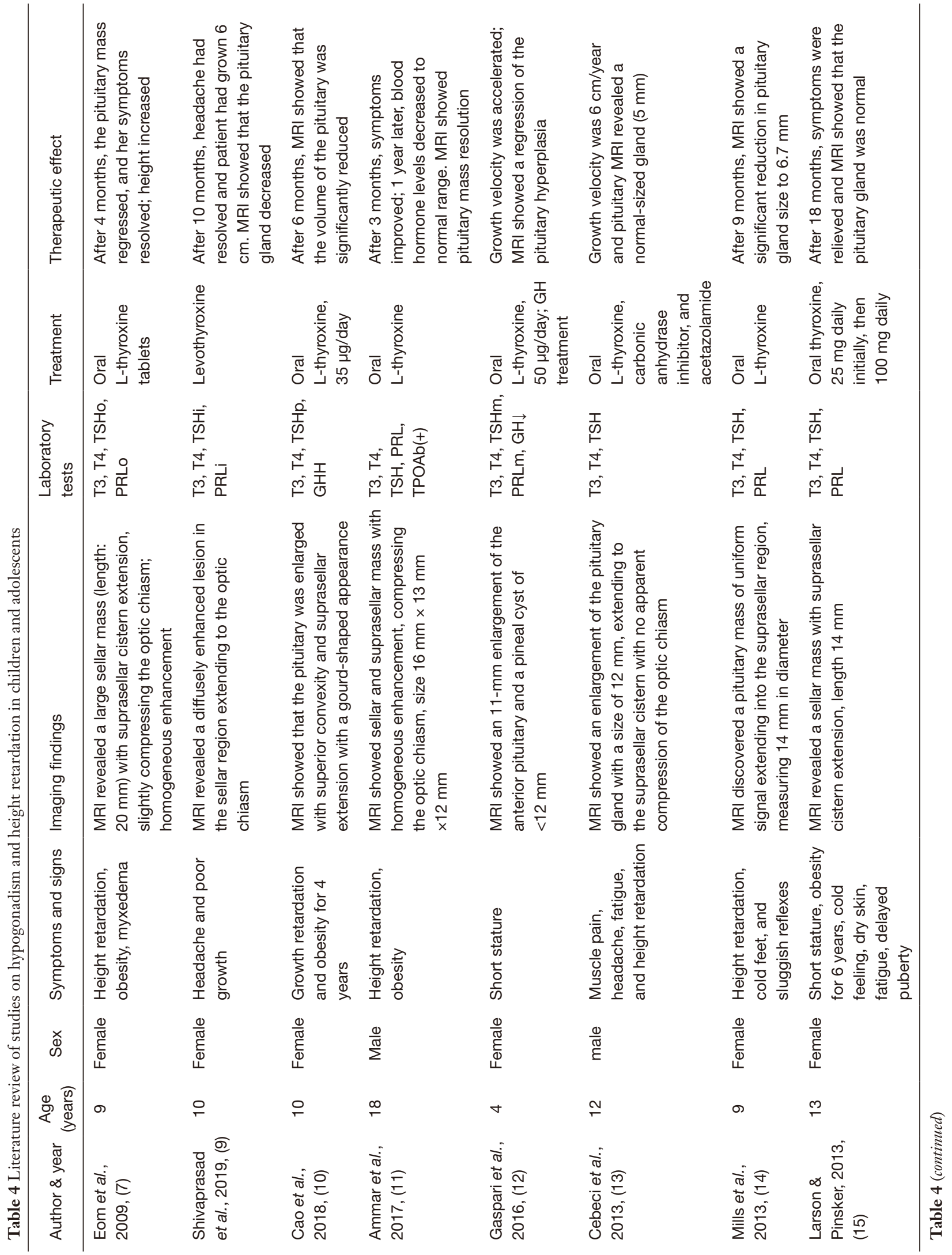




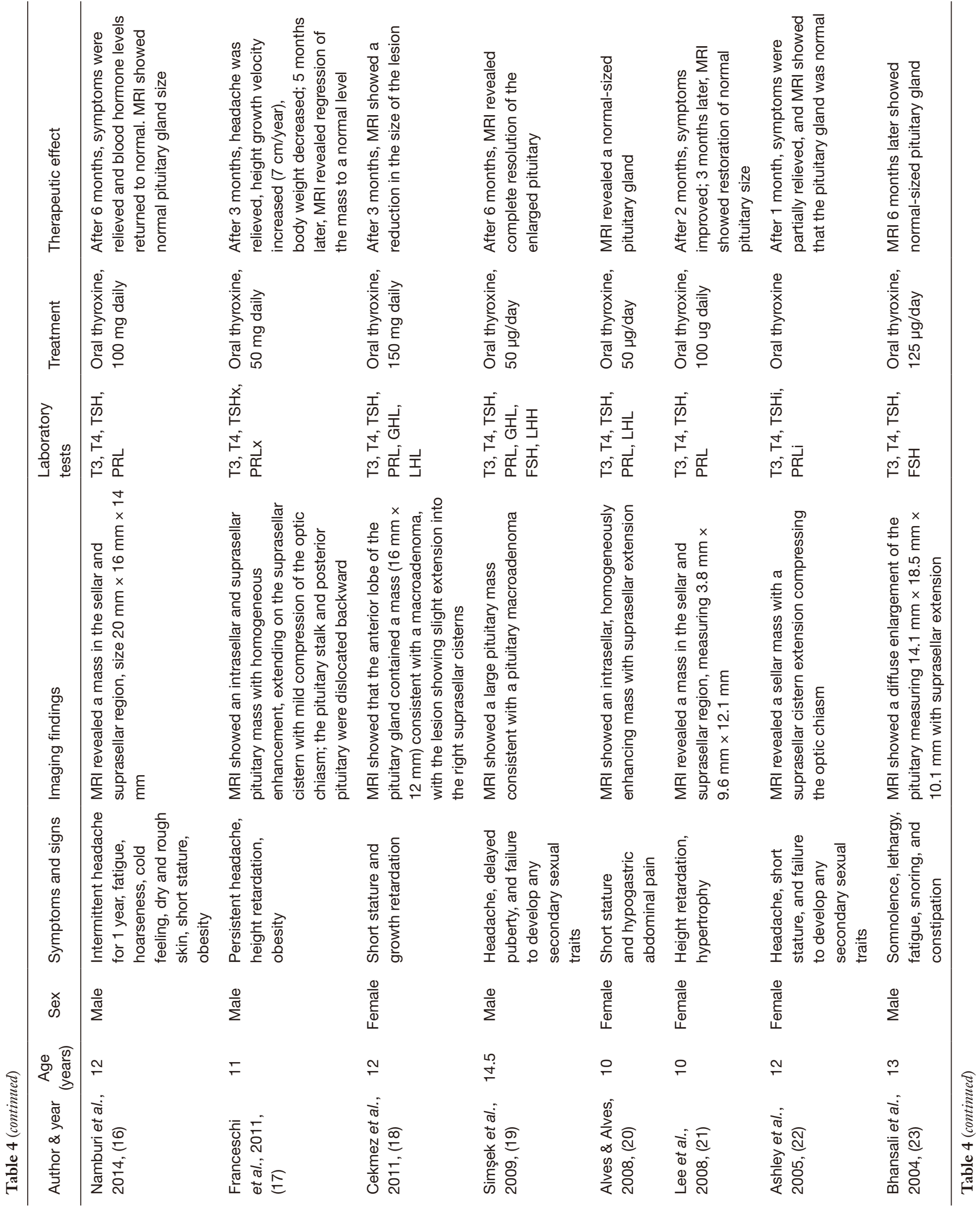




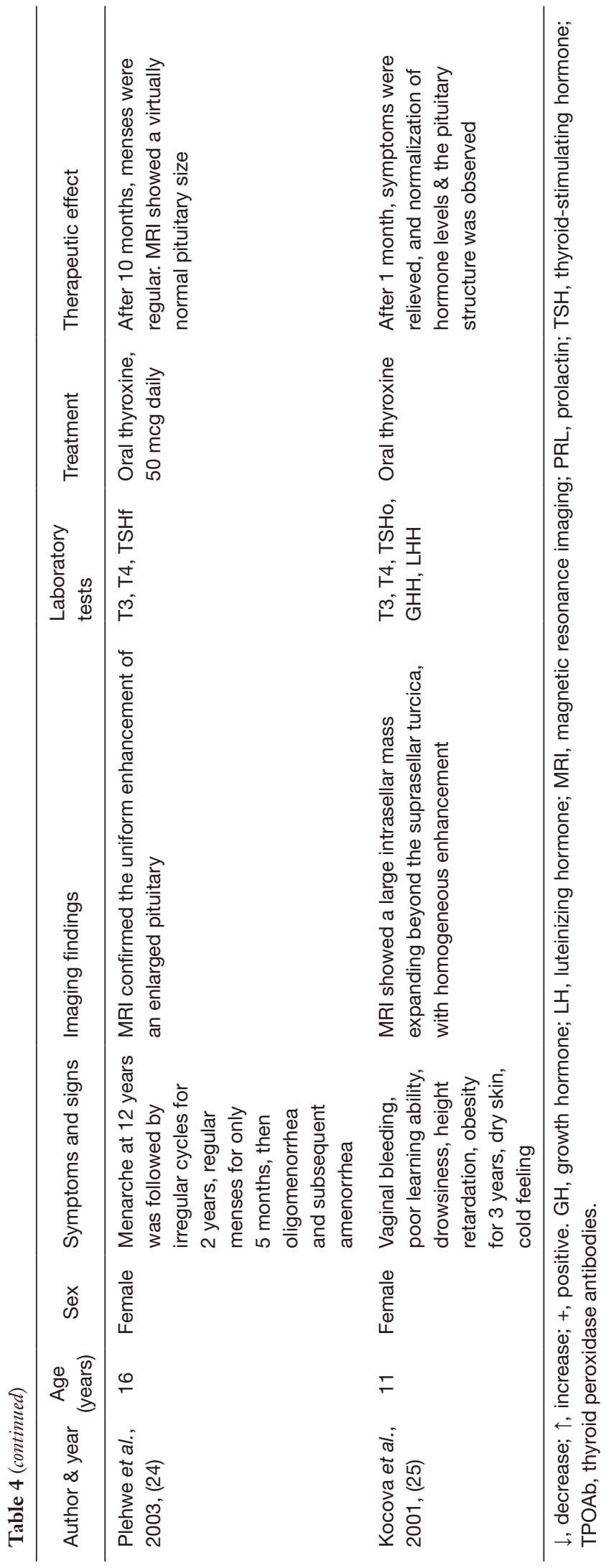

in the continuous reduction of thyroid hormone causes excessive secretion of TRH, and conduce to a proliferation of TSH secreting cells, which results in compensatory enlargement of the pituitary gland (10). Long-term primary hypothyroidism-induced pituitary hyperplasia has been confirmed by many studies (7,9-25).

In previously published reports on pituitary hyperplasia and associated hypothyroidism in children and adolescents, $42 \%$ of the main symptoms were found to be related to hypothyroidism and $45 \%$ to adolescent abnormalities (including precocious puberty and hypogonadotropic hypogonadism) (19). A small proportion of symptoms are related to tumor compression (including headache and visual impairment), prolactinoma (including amenorrhea and lactation), and secondary adrenal insufficiency (19). Approximately $3 / 4$ of patients have mild-to-moderate hyperprolactinemia due to the slight stimulation effect of TRH on prolactin cells (2). It is also believed that hypothyroidism-induced pituitary hyperplasia leads to compression of the pituitary stalk or a decrease in prolactin clearance in the circulatory system, which results in hyperprolactinemia (17). We reviewed the case reports of hypothyroidism with pituitary hyperplasia in children, but the number of studies on precocious puberty and hypogonadism is still too small, so more practical cases are needed to verify and summarize in the future.

Reports indicate that $45 \%$ of patients with pituitary hyperplasia have a GH deficiency, 13\% have high FSH and LH, and 27\% have low FSH and LH (19). Previous studies have shown that hypothyroidism can lead to decreased levels of sex hormone-binding globulin (SHBG), estrogen, and androgens (26). SHBG is a specific binding protein of testosterone and estradiol (27). By reducing SHBG synthesis, hypothyroidism promotes the conversion of androstenedione to testosterone and estradiol aromatase, which reduces the metabolic clearance of diketones and estrones (27-29). Patients with hypothyroidism can have normal, elevated, or decreased FSH and LH levels (30). Some patients with primary hypothyroidism have normal FSH and LH levels, whereas others have elevated serum FSH levels (30). High TRH levels can also stimulate the secretion of FSH (26). In the present study, the patient had high testicular volume in the absence of penis growth, and the laboratory examination results indicated a high FSH/ LH ratio. Studies have shown that high testicular volume can occur in the absence of penis growth, pubic hair, and pubertal growth spurt (31). This may indicate that there is a lack of harmony in both physical and sexual signs of 
growth period. This scenario in childhood is considered incomplete isosexual precocity (32). In adolescence, a loss of consonance of puberty indicates an underlying endocrine disorder, which may consist of long-standing primary hypothyroidism $(32,33)$. Other studies have confirmed that primary hypothyroidism could cause delayed pubertal development (33).

Radioimmunoassays can be used to detect FSH or LH levels, and increases in pubertal immunoreactivity and biologically active FSH (puberty) concentrations; however, LH cannot be detected via this method. Therefore, in the present study, the inspection results showed that LH was too low. It has been postulated that prolactin suppresses LH. Increased FSH release induces Sertoli cell proliferation, and a lack of LH leads to estrogen production; therefore, a high FSH/LH ratio (in contrast to that observed in normal puberty) seems to account for enlarged testes without signs of virilization (31). In 2009, Simşek et al. first reported a case of primary hypothyroidism with pituitary hyperplasia that caused a reduction of gonadotropins (FSH and LH) and GH (19). A 14.5-year-old adolescent male had headaches and underdeveloped secondary sexual characteristics. The long-term lack of GH and gonadotropin were thought to be related to the compression of the pituitary stalk by the enlarged pituitary gland (19). In the present study, we consider severe hypothyroidisminduced pituitary hyperplasia and subsequent reduction in the level of gonadotropin to be caused by the pituitary gland, resulting in hypogonadotropic hypogonadism. According to the etiology, hypogonadism can be divided into primary hypogonadism and secondary hypogonadism (hypogonadotropic hypogonadism). For the children with hypogonadism, the etiology should be clear, rather than simply supplement gonadal hormone. We can evaluate the signs of gonadal development, improve MRI of sellar region, measure gonadotropin and gonadal hormone, gene detection and so on, and make a comprehensive evaluation in combination with clinical practice: (I) significant increase of gonadotropin may indicate sellar region tumor; (II) the increase of gonadotropin and the decrease of gonadotropin often indicate primary gonadal dysfunction; (III) the increase of PRL may lead to hypothalamic pituitary disease and hypothyroidism; (IV) chromosomal abnormalities can also lead to hypogonadism (34). For the treatment of congenital hypogonadism, male patients should use short-term and low-dose testosterone as early as possible to induce penile growth $(35,36)$. In adolescence, the purpose of treatment is to induce secondary sexual characteristics and normal sexual function, which is often induced by oral testosterone/ estradiol $(37,38)$, in addition to gonadotropin therapy and gonadotropin releasing hormone pulse therapy (39). For patients with secondary hypogonadism, etiological treatment is the main treatment. If this case of primary hypothyroidism caused by hypogonadism, thyroid hormone replacement therapy should be used.

Pituitary biopsy of patients with hypothyroidism-induced pituitary hyperplasia confirms that there are specific cells in the pituitary gland that can produce both TSH and GH, and phenotypic changes impact them (40). Hypothyroidism promotes the differentiation and transformation of TSH cells to induce an increase in TSH levels and decrease GH secretion, affecting height development in children (40). Most children with primary hypothyroidism have growth retardation, and decreased GH secretion may also be related to this (40). First, animal experiments have confirmed that the human pituitary GH gene contains thyroid hormone response elements; thyroid hormone reduction leads to a decrease in their expression, which affects the secretion of GH. Second, hypothyroidism can damage the cholinergic channels, thereby affecting the secretion of GH (19). The reduction in GH caused by hypothyroidism is only temporary. Levothyroxine replacement therapy enables the GH level to return to normal, and results in complete or partial catch-up growth. It has been reported that preschool or school-aged children who undergo levothyroxine replacement therapy often achieve complete catch-up growth.

In contrast, children who undergo levothyroxine replacement therapy during puberty may achieve only partial catch-up growth (41). For children with hypothyroidism and associated GH deficiency, GnRH analogs can be used in combination with recombinant human GH to alter the height to that of their parents (12). In the present study, the patient's GH level was relatively low; we believe that the growth retardation was caused by hypothyroidism and decreased GH.

Many case reports have verified that primary hypothyroidism can lead to pituitary hyperplasia, and can also cause pituitary tumors $(10,42)$. Both pituitary hyperplasia and pituitary tumors have similar or high T2weighted angiography images (43). Some pituitary tumors have signals due to a large necrosis area, and this feature can make them difficult to distinguish from pituitary hyperplasia (43). Pituitary macroadenoma ( $>10 \mathrm{~mm}$ and $<4 \mathrm{~cm}$ ) can be easily observed to have uneven signals during plain and enhanced MRI scans due to necrosis, 
cystic changes, and hemorrhage (44). However, even if the pituitary hyperplasia mass is large enough, the signals are uniform and no area contains cystic and necrotic changes (45). When the pituitary adenoma grows on the saddle, the upper part of the saddle is often enlarged, and this development can also affect the cavernous sinus, clivus, sphenoid sinus, and other areas. It can also compress the optic chiasm and surround the internal jugular vein $(9,46)$.

Conversely, the MRI manifestation of pituitary hyperplasia is an enlargement of the pituitary gland, which grows on the saddle, but rarely involves the surrounding tissues (46). The standard posterior pituitary lobe signal shows a strong signal in the posterior lobe (10). The pituitary height of pituitary adenomas is also higher than that of pituitary hyperplasia, which may be related to the abnormal tumor tissue proliferation in the former (9). In dynamic contrast-enhanced scanning, patients with pituitary macroadenoma show thickening or enhancement of the dura mater, while patients with pituitary hyperplasia exhibit a slow-in and slow-out enhancement (9).

During the imaging examination of our case, there were iso-long T1 and slightly longer T2 nodular signals in the saddle area, and the enhanced lesions were slightly uneven, suggestive of a pituitary tumor. Diagnosis of a pituitary tumor without endocrine examination may result in unnecessary surgery and irreversible damage (6). One patient who is misdiagnosed as pituitary tumor and underwent surgery excision, due to a decrease in pituitary function, may lead to a higher incidence rate and mortality risk and lower quality of life (47). Anterior pituitary damage will lead to growth hormone deficiency, adrenocorticotropic hormone deficiency, thyroid stimulating hormone deficiency and gonadotropin deficiency (48). Damage to the posterior pituitary will lead to arginine vasopressin deficiency. Patients with hypopituitarism need lifetime monitoring of serum hormone levels and symptoms of hormone deficiency or excess. For patients with hypothyroidism, thyroid hormone replacement therapy can result in a satisfactory prognosis, as well as improvements in clinical symptoms and serologic values $(7,8)$. The pituitary function of those with pituitary hyperplasia can be slowly restored after negative feedback inhibition is rebalanced. However, patients with pituitary tumors should undergo surgery.

\section{Conclusions}

Hypothyroidism can involve multiple systems and organs. Cases of primary hypothyroidism characterized by hypogonadotropic hypogonadism are rare and are easily misdiagnosed. MRI is an effective method for distinguishing primary hypothyroidism combined with pituitary hyperplasia from pituitary tumors. When differentiation is difficult with MRI, levothyroxine replacement therapy can be undertaken to determine the diagnosis. Accurate differentiation can avoid incorrect or unnecessary surgery. The use of gonadal hormones can result in fully restored GH and gonadotropin levels, excellent gonadal development, and complete catch up in height. However, some cases with partial catch up in height may require gonadal hormones.

\section{Acknowledgments}

We gratefully acknowledge Yueyang Zhao for providing intellectual support and technical assistance.

Funding: This research was supported by the National Natural Science Foundation of China (No. 81700706), the 345 Talent Project of Shengjing Hospital, and the Clinical Research Project of Liaoning Diabetes Medical Nutrition Prevention Society (grant No. LNSTNBYXYYFZXHRS01B).

\section{Footnote}

Reporting Checklist: The authors have completed the CARE reporting checklist. Available at http://dx.doi.org/10.21037/ apm-20-1828

Conflicts of Interest: Both authors have completed the ICMJE uniform disclosure form (available at http://dx.doi. org/10.21037/apm-20-1828). The authors have no conflicts of interest to declare.

Ethical Statement: The authors are accountable for all aspects of the work in ensuring that questions related to the accuracy or integrity of any part of the work are appropriately investigated and resolved. All procedures performed in studies involving human participants were in accordance with the ethical standards of the institutional and/or national research committee(s) and with the Helsinki Declaration (as revised in 2013). Written informed consent was obtained from the patient.

Open Access Statement: This is an Open Access article distributed in accordance with the Creative Commons Attribution-NonCommercial-NoDerivs 4.0 International 
License (CC BY-NC-ND 4.0), which permits the noncommercial replication and distribution of the article with the strict proviso that no changes or edits are made and the original work is properly cited (including links to both the formal publication through the relevant DOI and the license). See: https://creativecommons.org/licenses/by-nc-nd/4.0/.

\section{References}

1. Hu YY. Characteristics of girls with pituitary hyperplasia and sexual precocity secondary to primary hypothyroidism. Acta Paediatr 2014;103:e43-8.

2. Beck-Peccoz P, Brucker-Davis F, Persani L, et al. Thyrotropin-secreting pituitary tumors. Endocr Rev 1996;17:610-38.

3. Nguyen-Michel VH, Schwald N, Hubert S, et al. Central hypothyroidism allows discovery of a pituitary disorder in older people. J Am Geriatr Soc 2007;55:630-1.

4. Koller KJ, Wolff RS, Warden MK, et al. Thyroid hormones regulate levels of thyrotropin-releasinghormone mrna in the paraventricular nucleus. Proc Natl Acad Sci U S A 1987;84:7329-33.

5. Faglia G, Bitensky L, Pinchera A, et al. Thyrotropin secretion in patients with central hypothyroidism: evidence for reduced biological activity of immunoreactive thyrotropin. J Clin Endocrinol Metab 1979;48:989-98.

6. Shimono T, Hatabu H, Kasagi K, et al. Rapid progression of pituitary hyperplasia in humans with primary hypothyroidism: demonstration with MR imaging. Radiology 1999;213:383-8.

7. Eom KS, See-Sung C, Kim JD, et al. Primary hypothyroidism mimicking a pituitary macroadenoma: regression after thyroid hormone replacement therapy. Pediatr Radiol 2009;39:164-7.

8. Riedl S. and H. Frisch. Pituitary hyperplasia in a girl with gonadal dysgenesis and primary hypothyroidism. Horm Res 1997;47:126-30.

9. Shivaprasad KS, Siddardha K. Pituitary hyperplasia from primary hypothyroidism. N Engl J Med 2019;380:e9.

10. Cao J, Lei T, Chen F, et al. Primary hypothyroidism in a child leads to pituitary hyperplasia: A case report and literature review. Medicine (Baltimore) 2018;97:e12703

11. Ammar M, HadjKacem F, Maalej A, et al. Pituitary hyperplasia due to primary hypothyroidism. Rev Med Interne 2017;38:844-6.

12. Gaspari L, Paris F, Leboucq N, et al. Reversible growth failure and complete GH deficiency in a 4-year-old girl with very early Hashimoto's thyroiditis and subsequent hyperplasia of pituitary thyrotroph cells. Eur J Pediatr 2016;175:1119-22.

13. Cebeci AN, Güven A, Saltik S, et al. Hoffmann's syndrome and pituitary hyperplasia in an adolescent secondary to Hashimoto thyroiditis. J Pediatr Endocrinol Metab 2013;26:747-51.

14. Mills NJ, Wong SC, Sabin MA, et al. Reactive pituitary hyperplasia associated with paediatric primary hypothyroidism. J Paediatr Child Health 2013;49:421-2.

15. Larson NS, Pinsker JE. Primary hypothyroidism with growth failure and pituitary pseudotumor in a 13-year-old female: a case report. J Med Case Rep 2013;7:149.

16. Namburi RP, Karthik TS, Ponnala AR. Autoimmune hypothyroidism presenting as pituitary hyperplasia. Indian J Pediatr 2014;81:937-9.

17. Franceschi R, Rozzanigo U, Failo R, et al. Pituitary hyperplasia secondary to acquired hypothyroidism: case report. Ital J Pediatr 2011;37:15.

18. Cekmez F, Pirgon O, Bilgin H. Pituitary macroadenoma due to primary hypothyroidism in a 12-year-old girl. $\mathrm{Br} \mathrm{J}$ Biomed Sci 2011;68:208.

19. Simşek E, Simşek T, Savaş-Erdeve S, et al. Pituitary hyperplasia mimicking pituitary macroadenoma in two adolescent patients with long-standing primary hypothyroidism: case reports and review of literature. Turk J Pediatr 2009;51:624-30.

20. Alves C, Alves AC. Primary hypothyroidism in a child simulating a prolactin-secreting adenoma. Childs Nerv Syst 2008;24:1505-8.

21. Lee CY, Hsu HH, Lai HY, et al. Rapid progression of hypothyroidism-related pituitary hyperplasia. J Neurosurg Pediatr 2008;2:212-4.

22. Ashley WW Jr, Ojemann JG, Park TS, et al. Primary hypothyroidism in a 12-year-old girl with a suprasellar pituitary mass: rapid regression after thyroid replacement therapy: case report. J Neurosurg 2005;102:413-6.

23. Bhansali A, Sreenivasulu P, Khandelwal N, et al. Reversibility of thyrotroph hyperplasia after L-thyroxine replacement therapy in patients with juvenile primary hypothyroidism. J Pediatr Endocrinol Metab 2004;17:655-61.

24. Plehwe WE, Fabinyi GC. Anterior pituitary hyperplasia due to primary autoimmune hypothyroidism. J Clin Neurosci 2003;10:217-8.

25. Kocova M, Netkov S, Sukarova-Angelovska E. Pituitary pseudotumor with unusual presentation reversed shortly after the introduction of thyroxine replacement therapy. J Pediatr Endocrinol Metab 2001;14:1665-9. 
26. Krassas GE, Perros P. Thyroid disease and male reproductive function. J Endocrinol Invest 2003;26:372-80.

27. Chopra IJ, Tulchinsky D. Status of estrogen-androgen balance in hyperthyroid men with Graves' disease. J Clin Endocrinol Metab 1974;38:269-77.

28. Olivo J, Southren AL, Gordon GG, et al. Studies of the protein binding of testosterone in plasma in disorders of thyroid function: effect of therapy. J Clin Endocrinol Metab 1970;31:539-45.

29. Ford HC, Cooke RR, Keightley EA, et al. Serum levels of free and bound testosterone in hyperthyroidism. Clin Endocrinol (Oxf) 1992;36:187-92.

30. Hu Y, Wang Q, Li G, et al. Ultrasonic morphology of uterus and ovaries in girls with pituitary hyperplasia secondary to primary hypothyroidism. Horm Metab Res 2013;45:669-74.

31. Styne D. editor. Physiology and disorders of puberty. Melmed S, Polonsky KS. Williams Textbook of Endocrinology 13th edition. hiladelphia: ELSEVIER, 2016.

32. Stanhope R. and CG Brook. Clinical diagnosis of disorders of puberty. Br J Hosp Med 1986;35:57-8.

33. Pringle PJ, Stanhope R, Hindmarsh P, et al. Abnormal pubertal development in primary hypothyroidism. Clin Endocrinol (Oxf) 1988;28:479-86.

34. Li T, Hu SC. Update of diagnosis and treatment for male hypogonadism in children. Chinese Journal of Child health Care 2018;26:10-2.

35. Hatipoğlu N, Kurtoğlu S. Micropenis: etiology, diagnosis and treatment approaches. J Clin Res Pediatr Endocrinol 2013;5:217-23.

36. Bin-Abbas B, Conte FA, Grumbach MM, et al. Congenital hypogonadotropic hypogonadism and micropenis: effect of testosterone treatment on adult penile size why sex reversal is not indicated. J Pediatr 1999;134:579-83.

37. Young J. Approach to the male patient with congenital hypogonadotropic hypogonadism. J Clin Endocrinol Metab
2012;97:707-18.

38. Dunkel L, Quinton R. Transition in endocrinology: induction of puberty. Eur J Endocrinol 2014;170:R229-39.

39. Boehm U, Bouloux PM, Dattani MT, et al. Expert consensus document: European Consensus Statement on congenital hypogonadotropic hypogonadism-pathogenesis, diagnosis and treatment. Nat Rev Endocrinol 2015;11:547-64.

40. Vidal S, Horvath E, Kovacs K, et al. Transdifferentiation of somatotrophs to thyrotrophs in the pituitary of patients with protracted primary hypothyroidism. Virchows Arch 2000;436:43-51.

41. Lee WM, Diaz-Espineira M, Mol JA, et al. Primary hypothyroidism in dogs is associated with elevated $\mathrm{GH}$ release. J Endocrinol 2001;168:59-66.

42. Han L, Wang J, Shu K, et al. Pituitary tumorous hyperplasia due to primary hypothyroidism. Acta Neurochir (Wien) 2012;154:1489-92; discussion 1492.

43. Nawar RN, AbdelMannan D, Selman WR, et al. Pituitary tumor apoplexy: a review. J Intensive Care Med 2008;23:75-90.

44. Papakonstantinou O, Bitsori M, Mamoulakis D, et al. MR imaging of pituitary hyperplasia in a child with growth arrest and primary hypothyroidism. Eur Radiol 2000;10:516-8.

45. Hopper NW, Albanese A. Primary hypothyroidism in a child mimicking a pituitary macroadenoma. Horm Res 2005;63:61-4.

46. Wolansky LJ, Leavitt GD, Elias BJ, et al. MRI of pituitary hyperplasia in hypothyroidism. Neuroradiology 1996;38:50-2.

47. Romero CJ, Nesi-Franca S, Radovick S. The molecular basis of hypopituitarism. Trends Endocrinol Metab 2009;20:506-16.

48. Yeliosof O, Gangat M. Diagnosis and management of hypopituitarism. Curr Opin Pediatr 2019;31:531-6.
Cite this article as: $\mathrm{Yu} \mathrm{W}, \mathrm{Wu} \mathrm{N}$. Primary hypothyroidism with pituitary hyperplasia characterized by hypogonadotropic hypogonadism: a case report and review of the literature. Ann Palliat Med 2020;9(6):4359-4370. doi: 10.21037/apm-20-1828 